\title{
Real Exchange Rate Misalignment and Economic Growth in Belt \& Road Countries: The Role of Financial Integration
}

\author{
Hameed Khan* \\ Ph.D Scholar of School of Economics, Jilin University, Changchun, China. \\ Kohat University of Science \& Technology, Pakistan \\ Umair Khan* \\ Kohat University of Science \& Technology, Pakistan \\ Waqas Ali \\ School of Economics, Jilin University, Changchun, China \\ Professor Dr. Li Jun Jiang \\ Scholar of School of Economics, Jilin University, Changchun, China
}

\begin{abstract}
Competitive exchange rate is an important tool for the economies to boost the exports and raise foreign exchange reserves. The strategy is handy when the countries are economically open to the world. BRI (Belt \& Road Initiative) countries are financially integrated with each other through the foreign capital. This study seeks to investigate the role of financial integration in the relationship between real exchange rate misalignment and economic growth in Belt \& Road countries during 2001-2016 and 2013-2016 by applying the generalized method of moment (GMM). Using grouped and ungrouped samples; the results reveal that the real exchange rate plays a significant and positive role in economic growth. Financial integration also plays a significant and positive role in economic growth. The interaction terms of the real exchange rate and financial integration play a significant and negative role in economic growth. Moreover, several robustness checks like two-stage least squares, fixed and random effect models also confirms the results of the GMM approach. Furthermore, policy recommendation can be drawn from this study, like capital shortage can be adjusted by applying a competitive exchange rate policy.
\end{abstract}

Keywords: Real exchange rate misalignment; economic growth; financial integration; Belt \& Road countries.

JEL Classification: O11, F43, F31

DOI: $10.7176 / \mathrm{DCS} / 9-10-06$

Publication date:October $31^{\text {st }} 2019$

\section{1- Introduction}

Much evidence exit to support the view that economic growth is affected by the real exchange rate (Bleaney \& Greenaway, 2001; Gala, 2008; Razin \& Collins, 2010). One position-call it the "Washington Consensus" (WC) that is based on the neo-classical view-proposed that an equilibrium real exchange rate (RER) is constrained by supply-side factors to promote growth (Williamson, 1990). The influence of undervaluation on economic growth is the subject of a growing debate among the researchers and policymakers since they agree that developing countries should avoid overvaluation.

The growth-enhancing effects of undervaluation are supported by a plethora of studies (Béreau, Villavicencio, \& Mignon, 2012; Bleaney \& Greenaway, 2001; Dai, Delpachitra, \& Cottrell, 2016; Gala, 2008; Hausmann, Pritchett, \& Rodrik, 2005; Razin \& Collins, 2010). The effect of undervaluation on growth is more significant in the case of developing countries (Razmi, Rapetti, \& Skott, 2012; Vieira \& MacDonald, 2012). On the other hand, the recent studies present counterevidence regarding the influence of undervaluation on growth (Nouira \& Sekkat, 2012; Schröder, 2013). The counterevidence of the undervaluation-growth linkage stresses the importance of revealing the channels of influence of undervaluation instead of emphasizing the correlation between economic growth and undervaluation.

The theoretical explanation of the relationship between growth and undervaluation is still limited, although a large number of studies empirically tested the relationship. The hypotheses focus on the undervaluation's role in stimulating capital accumulation (Gala, 2008; Ibarra, 2011; Razmi et al., 2012), and supporting trade (Dogru, Isik, \& Sirakaya-Turk, 2019; Lin, Shi, \& Ye, 2018). Undervaluation significantly influences saving and employment (Dai \& Xu, 2017). Porcile \& Lima (2010) provide a balance-of-payments constrained macrodynamic model that explains the impact of undervaluation through both channels. Devaluation releases constraints on the balance of payment and increases a country's exports, which ultimately increases the level of investment. Hamper

There are various channels through which exchange rate affect economic growth. When a country devalues its currency, its exports rise due to increased demand of currency. On the other hand, the prices of imports are rise, which improves the balance of trade due to the decreased volume of imports. The surplus foreign exchange 
reserves may be utilized for the imports of raw materials. Similarly, devaluation enhanced the scale of production through the increased volume of sales in foreign markets. In East Asian countries, the inward-oriented policies associated with overvalued currencies obstructed economic growth, while the outward-oriented policies ${ }^{1}$ encouraged economic growth and trade of these regions (Cottani, Cavallo, \& Khan, 2005; Dollar, 2005).

In short, those countries suffer from a balance of payments constraints and foreign capital shortage that are less financially integrated. Undervaluation could offset the foreign capital shortage by improving the trade balance, release the balance of payments constraints, and ultimately boost investment and economic growth. By contrast, in a country with a high degree of financial integration, foreign capital inflows could eliminate the balance of payments constraints, and hence the investment-enhancing effect of devaluation could be insignificant.

Considering the conflicting results of previous studies; our study aims to investigate the relationship between undervaluation and growth by assuming that financial integration is an essential factor for the successful implementation of exchange rate policy (Dai et al., 2016). Based on Dai, Delpachitra, \& Cottrell ( 2016); and Porcile \& Lima (2010)'s models that explain the operation of the capital accumulation channel; this study proposes that the competitive RER effect on economic growth assumes to be robust in the BRI countries having low levels of financial integration. Unlike the previous studies that focus on the aggregate sample of countries; this study employ grouped and ungrouped data of BRI countries. We also try to overcome the shortcomings of the previous studies by analyzing the data in various time durations. Moreover, to counter the potential endogeneity issue; this study employs the generalized method of moment (GMM) technique. For robust analysis, we use two-stage least squares (2SLS), estimator. Similarly, we apply time dummy is incorporated to show the impact RER misalignment on growth by fixed and random effect models.

This paper is organized as follows. Section 2 describes the empirical models used to test the underlying hypothesis. Section 3 presents an estimation strategy, regression results, and implications. Section 4 provides the conclusion.

\section{2- Model specification and data}

\subsection{RER misalignment estimation}

There are three different approaches through which one can estimate RER. The $1^{\text {st }}$ approach is the general equilibrium, $2^{\text {nd }}$ is the partial equilibrium, and the $3^{\text {rd }}$ approach is the reduced equation approach. All three methods have their advantages and disadvantages. Since most of the developing countries' data is not readily available; hence, the general equilibrium is not a good approach. However, the approach has a strong theoretical foundation. The general equilibrium approach suffers from the measurement error for developing countries that have lower economic development.

On the other hand, the partial equilibrium approach produces unreliable estimates, and it also depends on many assumptions. The reduced equation is the right approach for the real exchange rate (RER) misalignment. Moreover, the reduced equation approach is a simple approach. However, because of the strong homogeneity assumption in cross-country analysis, the method also has some limitations.

In this paper, we apply the reduced equation method to estimate the RER misalignment index (Edwards, 1988; Elbadawi, Kaltani, \& Schmidt-hebbel, 2008; Razin \& Collins, 2010). There are three steps in constructing the index. In the first step, we estimate RER. In this step nominal exchange rate (NER) is adjusted for price index. We use GDP deflator and consumer price index as price indices.

$$
R E R_{i t}=\frac{N E R_{\mathrm{it}}}{N E R_{i}^{*}} \frac{P_{i}^{*}}{P_{\mathrm{it}}} \frac{P I_{u s, t}}{P I_{u s}^{*}}
$$

Where $i$ and $t$ represent country and year, respectively. Similarly * represents value in the base year.

The second step involves the econometric model as shown below;

$\widehat{R E R_{l t}}=\beta_{0}+\beta_{1} G D P R_{i t}+\beta_{2} T O T_{i t}+\beta_{3} O P E N_{i t}+\beta_{4} F D I_{i t}+\mu_{i t}$

Where GDPR is a country per capita GDP to US per capita GDP. TOT represents terms of trade; OPEN is exports plus imports value divided by GDP; FDI represents the ratio of foreign direct investment by GDP. The fitted values of RER represent the equilibrium RER.

In the third step, we compute the RER misalignment index (RERMIS), i.e., the ratio of RER to equilibrium RER. The RERMIS can be represented as follows;

$$
R E R M I S_{i t}=\frac{R E R_{i t}}{R \widetilde{R R}_{l t}}
$$

If the value of RERMIS is greater than 1, then there is undervaluation in the exchange rate. Similarly, if the value is less than 1 , then there is overvaluation in the exchange rate.

\subsection{Econometric specification of the economic growth}

Through the channel of financial integration, we estimate the relationship between RER misalignment and economic growth. We compute various specifications of the model by introducing interaction terms in the baseline

\footnotetext{
1 The policies which are expressed in terms of a devalued currency.
} 
model. The model can be written as follows;

$G_{D P P C G}=\beta_{0}+\beta_{1} R E R M I S_{i t}+\beta_{2} R E R M I S * F D I_{i t}+\beta_{3} F O P E N_{i t}+\beta_{3} F I_{i t} *$ FOPEN + $\sum_{p=1}^{l} \varnothing$ CONTROL $L_{i t}+\mu_{i t} \ldots \ldots \ldots$ Equation (4)

Where GDPPCG is per capita GDP rate; RERMIS is RER misalignment index; FDI is foreign direct investment showing the degree of financial integration; RERMIS * FDI is the interaction term of RER and FDI; FOPEN is capital openness index devised by Chinn \& Ito (2008); and RERMIS*FOPEN represent interaction between RER and FOPEN. Similarly, CONTROL indicates the vector of control variables used in this study. The control variables consist of the ratio of gross fixed capital formation to GDP, inflation, and share of government spending to GDP.

We incorporate various measures of financial integration. Firstly we employ FDI as a percent of GDP, and secondly, we have Chinn \& Ito (2008) financial openness indicator.

\subsection{Data}

Table 1 shows the data and its sources. It can be seen that most of the data is taken from World Bank. However, the financial openness indicator is taken from Chinn \& Ito (2008). Rather than merely measuring the capital control intensity, the Chinn \& Ito (2008) index aim to capture the level of capital openness.

Table 1. Data

\begin{tabular}{lll}
\hline Variable & Description & Source \\
\hline FOPEN & Financial openness indicator & Chinn \& Ito (2008) \\
\hline FDI Inflow & Foreign direct investment inflow & UNCTAD (2018) \\
FDI Stock & Foreign direct investment stock & \\
\hline GDPPC & GDP per capita (constant 2010 USD) & \\
GE & General government final consumption expenditure (\% of GDP) & \\
GFCF & Gross fixed capital formation (\% of GDP) & World Bank (2018) \\
INF & Inflation rate (annual \%) & \\
GDP & Gross domestic product (current USD and constant 2010 USD) & \\
GDPPCG & Real GDP growth rate (annual \%) & \\
DLF & GDP deflator (base year varies by country) & \\
CPI & Consumer price index (year 2010=100) \\
NER & Official exchange rate (LCU per USD, period average) & \\
\hline
\end{tabular}

\subsection{Estimation methodology}

New growth theories suggest that per capita GDP, exchange rate, and FDI are likely to be endogenous variables. If this is the case, straightaway panel estimation will yield biased results. Therefore, a test for endogeneity should be applied. If the null hypothesis of exogeneity is rejected, per capita growth, RERMIS and FDI should be treated as endogenous variables and an instrumental variable method - the generalized method of moments (GMM) will be employed (Baltagi, 2005; MW \& Enders, 2006). The tricky issue in GMM methodology is to select valid instruments/moments. No rule of thumb exists in instruments' selection. For this purpose, various tricks have been discussed by Murray (2007). The advantage of GMM over other instrumental variables (IV) methods is that a GMM estimator is more efficient than an IV estimator if heteroscedasticity is present, whereas a GMM estimator is not worse asymptotically than an IV estimator if heteroscedasticity is not present. In this study, the lagged values of independent variables have been used as instruments. For robustness check, we apply the 2SLS method.

The mentioned estimation techniques in this study are applied on aggregated and disaggregated data (by decomposing global sample into various groups like Asia, Europe, and Africa) for multiple periods (2000-2016, 2013-2016, and 2009-2012). The intention for this disaggregation is to watch the effect of financial integration on BRI countries closely. Similarly, the purpose of dividing the period is to see the impact of BRI initiative on the relationship.

For robust analysis, we use fixed and random effect models by including time dummy on the aggregate data (global sample). For this purpose, we will divide data into two parts, i.e., 2009-2012 and 2013-2016, by assigning 0 to the former and 1 for the later. Comparative to the random and fixed effect models that are not restricted, the pooled model is restricted and assumes that countries are homogeneous. When it is necessary to control for omitted variables that are constant over time but differ between countries, the fixed-effects model is desirable. Since the fixed effect considers heterogeneity and individual country effects, therefore, it gives better estimates than the pooled model.

On the other hand, no individual country effects are assumed in the random effects model. To test this assumption and to compare the fixed and random effects estimates, Hausman (2006) test is employed. Hausman test specifies whether the explanatory variables are correlated with specific effects or not. Hausman test makes sure the selection of the model with consistent results. Random effects are not correlated with the explanatory variables is the central assumption in random effects estimation. The fixed effects model is feasible if the p-value 
is significant, i.e., $<5 \%$. On the other hand, if it is greater than $5 \%$, then the most appropriate model is the randomeffects model.

\section{3- Results}

The baseline estimation methodology consists of the system generalized method moments (GMM). Table 2 to Table 5 reports the results of the growth equation for different groups from 2001 through 2016. Each table displays the results of eight regressions (GMM and 2SLS). 2SLS is employed to check the robustness of the results. Each regression includes baseline model; and the models with interaction terms and control variables. The column headings 1, 2, 3, and 4 represent various specifications. In this analysis, we exclude some countries based on nonavailability of data (countries' list available in the Appendix, Table A1). Similarly, we exclude the countries in Oceania and South America from the disaggregated analysis; however, we include them in the aggregated sample (global sample). Table 6 shows the robustness results whereby we replace FDI inflow to FDI stock.

Similarly, Table 7 to Table 10 reports the results of the growth equation from 2013 through 2016 . The period is selected on the ground that BRI was in its initial phase in the year 2013. Table 11 introduces FDI stock instead of FDI inflow to check the robustness of the results. Table 12 shows the results of fixed and random effect models.

1- Estimation results for different groups of countries during 2001-2016

The results in Table 2 show the global sample during 2001-2016. The results show that RERMIS has a positive and significant impact on growth in all the specifications. The positive coefficients demonstrate that a more competitive RERMIS could result in a higher rate of economic growth. Moreover, as the model captures a linear relationship between RER misalignment and growth, the result also means that a higher degree of overvaluation reduces economic growth. These results are consistent with previous studies (Béreau et al., 2012; Bleaney \& Greenaway, 2001; DAI et al., 2016; Gala, 2008; Hausmann et al., 2005; Razin \& Collins, 2010).

Similarly, inflow of FDI is proxy for the degree of financial integration, and an economy is considered to be highly financial integrated and open if its ratio of FDI inflow to GDP is high and it is supported by numerous studies (Abbas \& Christensen, 2010; Mankiw, Romer, \& Weil, 1992; Pattillo, Poirson, \& Ricci, 2002). Consistent with expectations, openness is growth enhancing. It is supported by (Lucas, 1988; Pattillo et al., 2002). The reason is that greater openness of an economy to the outside world represents improved competitiveness and productivity of the economy, which leads towards better economic performance. The results FDI is positively significant in all specifications except for the last one.

The coefficients of the interaction terms between RER misalignment and FDI were found to be significantly negative at the $1 \%$ level in regression 2 , which implies that the growth-enhancing effect of a competitive RER is more robust in less financially integrated countries, as expected. Supposing a rise in the level of undervaluation or a decrease in the level of overvaluation, the less financially integrated a country is the more its growth rate increases. Chinn \& Ito ( 2008)'s capital openness index replaced FDI in the regressions 3 \& 4 to proxy for financial integration. The coefficient of the interaction term is negative and significant at the $1 \%$ level. Due to the construction of the capital openness index, a higher value of the index indicates a higher degree of financial integration. The result, therefore, demonstrates a stronger positive impact of a competitive exchange rate on less financially integrated countries.

$\underline{\text { Table } 3}$, 4, and $\underline{5}$ show the results of Asia, Europe, and Africa in BRI during 2001-2016. The results show that RERMIS has a positive and significant impact on growth in Asia's group all the specifications except the specification 4; the results are not significant for Europe although the coefficient of RERMIS is positive, and the results for African group are significant for specification $1 \& 3$ but insignificant for $2 \& 4$. Similarly, the coefficients of interaction terms are insignificant for Asia and Africa, but the same is significant for Europe. The signs of the control variables are according to economic theory. For robustness check, we replace FDI stock to FDI inflow, and the results are given in Table 6. The inclusion of FDI stock confirm the results that RERMIS positively and significant influence growth. Similarly, it also confirms the results that interaction terms negatively and significantly influence growth.

1- Estimation results for different groups of countries during 2013-2016

Table 7 shows the results in the global sample during 2013-2016. It reveals that RERMIS has a positive and significant impact on growth in all the specifications. The coefficient of the interaction term between RER misalignment and FDI found significant negative. The interaction term between RER misalignment and capital openness is also found to be significant and negative. The coefficients of the interaction term between capital openness indicator and RER misalignment is negative and significant at the $1 \%$ level.

$\underline{\text { Table } 8}$, Table 9, and Table 10 show the results of Asia, Europe, and Africa in BRI during 2013-2016. The period is selected because the Belt \& Road Initiative was in the initial phase in 2013. The results show that RERMIS has a positive and significant impact on growth in Asia's group specifications $1 \& 3$ but insignificant for specification $2 \& 4$; the results are not significant for Europe although the coefficient of RERMIS is positive, and the results for African group are significant for all specifications except the specification 4. Similarly, the coefficients of interaction terms are significant for Asia and Africa, but the same is significant for Europe. The 
signs of the control variables are according to economic theory. For robustness check, we replace FDI stock to FDI inflow, and the result are given in Table 11. The inclusion of FDI stock confirm the results that RERMIS positively and significant influence growth. Similarly, it also confirms the results that interaction terms negatively and significantly influence growth.

Table 12 shows the results of fixed and random effect models of the global sample. For all the regressions; fixed effects and random-effects models are estimated. Hausman test suggests that random effect estimation is the proper strategy. Following the economic theory, all the variables have significant with correct signs. We use a robust method, i.e., White's heteroscedasticity-corrected covariance matrix estimator. Without altering the estimates of the slope coefficients, the approach allows for improving standard errors. ${ }^{1}$

The result shows that competitive RER misalignment is positively significant for regression 1 and 4 . The results for FDI and its interaction term are insignificant. The capital openness indicator is significant in specification 3 and 4. Similarly, the interaction term between capital openness and RER misalignment is significantly negative in specification 3 and 4. Time dummy is significantly positive in specification 1 and 4 .

Overall the results show that RER misalignment has a significant positive impact on per capita growth in Belt $\&$ Road countries. Similarly, financial integration

Table-2. Growth equation's results 2001-2016 - All BRI countries

\begin{tabular}{|c|c|c|c|c|c|c|c|c|}
\hline \multirow{3}{*}{ Explanatory Variables } & \multicolumn{8}{|c|}{ Global Group-I } \\
\hline & \multicolumn{2}{|c|}{1} & \multicolumn{2}{|c|}{2} & \multicolumn{2}{|c|}{3} & \multicolumn{2}{|c|}{4} \\
\hline & $G M M$ & $2 S L S$ & GMM & $2 S L S$ & GMM & $2 S L S$ & GMM & $2 S L S$ \\
\hline GDPPCG $_{\mathrm{t}-1}$ & $\begin{array}{l}0.23 * \\
(0.00)\end{array}$ & & $\begin{array}{l}0.24^{*} \\
(0.00)\end{array}$ & & $\begin{array}{l}0.23^{*} \\
(0.00)\end{array}$ & & $\begin{array}{l}0.23^{*} \\
(0.00)\end{array}$ & \\
\hline RERMIS & $\begin{array}{r}0.18 * * \\
(0.02)\end{array}$ & $\begin{array}{l}0.05 * \\
(0.02)\end{array}$ & $\begin{array}{l}0.66^{*} \\
(0.06)\end{array}$ & $\begin{array}{l}0.11 * * * \\
(0.06)\end{array}$ & $\begin{array}{l}0.19^{*} \\
(0.02)\end{array}$ & $\begin{array}{l}0.03 \\
(0.05)\end{array}$ & $\begin{array}{l}0.02 \\
(0.06)\end{array}$ & $\begin{array}{l}0.98 * * \\
(0.47)\end{array}$ \\
\hline \multicolumn{9}{|c|}{ Proxies for financial integration and interaction terms } \\
\hline $\begin{array}{l}\text { FDI } \\
\text { RERMIS*FDI }\end{array}$ & $\begin{array}{l}3.26^{*} \\
(2.55)\end{array}$ & $\begin{array}{r}9.56 * * * \\
(5.38)\end{array}$ & $\begin{array}{l}3.14^{*} \\
(2.31) \\
-1.83^{*} \\
(1.36)\end{array}$ & $\begin{array}{l}1.44 * * \\
(1.37) \\
-1.60 \\
(1.21)\end{array}$ & $\begin{array}{l}2.81^{*} \\
(1.88)\end{array}$ & $\begin{array}{l}8.67 \\
(8.77)\end{array}$ & $\begin{array}{l}3.01 * \\
(2.14)\end{array}$ & $\begin{array}{l}1.39 \\
(4.97)\end{array}$ \\
\hline $\begin{array}{l}\text { FOPEN } \\
\text { RERMIS* FOPEN }\end{array}$ & ables & & & & $\begin{array}{l}10.20 * \\
(0.49)\end{array}$ & $\begin{array}{l}1.68 * \\
(0.63)\end{array}$ & $\begin{array}{l}9.08^{*} \\
(0.56) \\
-0.57^{*} \\
(0.08)\end{array}$ & $\begin{array}{l}23.9 * \\
(9.16) \\
-1.41 * * * \\
(0.95)\end{array}$ \\
\hline & $1.27 *$ & $0.10 * * *$ & $1.58 *$ & $0.10 * * *$ & $1.29 *$ & $0.07 * * *$ & $1.46^{*}$ & $7.86^{*}$ \\
\hline GE & $(0.03)$ & $(0.06)$ & $(0.05)$ & $(0.06)$ & $(0.02)$ & $(0.04)$ & $(0.05)$ & $(2.57)$ \\
\hline GFCF & $0.35^{*}$ & $0.16 *$ & $0.39 *$ & $0.16^{*}$ & $0.33^{*}$ & $0.14^{*}$ & $0.34 *$ & 0.05 \\
\hline GFCF & $(0.01)$ & $(0.05)$ & $(0.01)$ & $(0.05)$ & $(0.01)$ & $(0.03)$ & $(0.01)$ & $(0.16)$ \\
\hline INF & $\begin{array}{l}-0.12 * \\
(0.00)\end{array}$ & $\begin{array}{r}-0.02 * \\
(0.03)\end{array}$ & $\begin{array}{c}-0.12^{*} \\
(0.01)\end{array}$ & $\begin{array}{l}-0.02 \\
(0.03)\end{array}$ & $\begin{array}{l}-0.13^{*} \\
(0.00)\end{array}$ & $\begin{array}{l}-0.01 \\
(0.02)\end{array}$ & $\begin{array}{r}-0.13^{*} \\
(0.01)\end{array}$ & $\begin{array}{l}-0.52 * * \\
(0.23)\end{array}$ \\
\hline $\begin{array}{l}\text { No. of observations } \\
\text { Hansen J-stat (p-vale) }\end{array}$ & $\begin{array}{l}910 \\
63.76 \\
(0.31)\end{array}$ & 975 & $\begin{array}{l}910 \\
58.25 \\
(0.46)\end{array}$ & 975 & $\begin{array}{l}910 \\
58.05 \\
(0.47)\end{array}$ & 975 & $\begin{array}{l}910 \\
61.64 \\
(0.31)\end{array}$ & 975 \\
\hline $\begin{array}{l}\text { AR (1) } \\
\operatorname{AR}(2)\end{array}$ & $25.13 *$ & $\begin{array}{l}-2.14 * * \\
0.82\end{array}$ & $14.44 * *$ & $\begin{array}{l}-1.62 * * * \\
0.76\end{array}$ & $35.98^{*}$ & $\begin{array}{l}-2.90 * * * \\
-1.24\end{array}$ & $32.54 *$ & \\
\hline
\end{tabular}

Note: ***, and $* * *$ represents significance at $1 \%, 5 \%$ and $10 \%$ respectively. The coefficient of constant is ignored. Robust standard errors are in parenthesis. Hansen J-stat p-values are in parenthesis. GMM results are reported for two-step GMM estimator

\footnotetext{
${ }^{1}$ The SE $(\beta)$ s should be estimated in a manner that may not alter the estimates of the slope coefficients because heteroscedasticity cause problems with standard errors but not cause the problem to the coefficients.
} 
Table 3. Growth equation's results 2001-2016 - Asia

\begin{tabular}{|c|c|c|c|c|c|c|c|c|}
\hline \multirow{3}{*}{$\begin{array}{l}\text { Explanatory } \\
\text { Variables }\end{array}$} & \multicolumn{8}{|c|}{ Asia Group-2 } \\
\hline & \multicolumn{2}{|c|}{1} & \multicolumn{2}{|c|}{2} & \multicolumn{2}{|c|}{3} & \multicolumn{2}{|l|}{4} \\
\hline & $G M M$ & $2 S L S$ & $G M M$ & $2 S L S$ & $G M M$ & $2 S L S$ & GMM & $2 S L S$ \\
\hline $\begin{array}{l}\text { GDPPCG }_{\mathrm{t}-1} \\
\text { RERMIS }\end{array}$ & $\begin{array}{l}0.03 * \\
(0.01) \\
0.22 * \\
(0.07)\end{array}$ & $\begin{array}{l}0.03^{*} \\
(0.01)\end{array}$ & $\begin{array}{l}0.03^{*} \\
(0.01) \\
0.19^{* * *} \\
(0.01)\end{array}$ & $\begin{array}{l}0.11 * * * \\
(0.06)\end{array}$ & $\begin{array}{l}0.03^{*} \\
(0.00) \\
0.16^{* *} \\
(0.07)\end{array}$ & $\begin{array}{l}0.06 \\
(0.15)\end{array}$ & $\begin{array}{l}0.01 \\
(0.01) \\
0.42 \\
(0.91)\end{array}$ & $\begin{array}{l}0.02 \\
(0.02)\end{array}$ \\
\hline \multicolumn{9}{|c|}{ Proxies for financial integration and interaction terms } \\
\hline FDI & $\begin{array}{l}21.12 * \\
(5.36)\end{array}$ & $\begin{array}{r}9.56 \\
* * * \\
(5.38)\end{array}$ & $\begin{array}{l}19.71 * \\
(6.24)\end{array}$ & $\begin{array}{l}8.37^{*} \\
(2.91)\end{array}$ & $\begin{array}{l}22.46^{*} \\
(5.56)\end{array}$ & $\begin{array}{l}6.77 \\
(11.99)\end{array}$ & $\begin{array}{l}19.25^{*} \\
(5.54)\end{array}$ & $\begin{array}{l}19.42 * \\
(5.55)\end{array}$ \\
\hline RERMIS*FDI & & & $\begin{array}{l}-0.74 \\
(1.22)\end{array}$ & $\begin{array}{l}-0.74 \\
(1.22)\end{array}$ & & & & \\
\hline $\begin{array}{l}\text { FOPEN } \\
\text { RERMIS* FOPEN }\end{array}$ & & & & & $\begin{array}{l}12.21^{*} \\
(1.97)\end{array}$ & $\begin{array}{l}2.71 \\
(3.35)\end{array}$ & $\begin{array}{l}15.2 * \\
(2.51) \\
-0.7 \\
(1.02)\end{array}$ & $\begin{array}{l}5.02 * \\
(1.55) \\
-0.01 \\
(0.03)\end{array}$ \\
\hline \multicolumn{9}{|c|}{ Inclusion of control variables } \\
\hline GE & $\begin{array}{l}0.17 * * \\
(0.07)\end{array}$ & $\begin{array}{r}0.07 \\
(0.05)\end{array}$ & $\begin{array}{l}0.17 * \\
(0.07)\end{array}$ & $\begin{array}{l}0.07 \\
(0.05)\end{array}$ & $\begin{array}{l}0.49 * \\
(0.09)\end{array}$ & $\begin{array}{l}0.23 \\
(0.53)\end{array}$ & $\begin{array}{l}0.08 \\
(0.06)\end{array}$ & $\begin{array}{l}0.03 \\
(0.07)\end{array}$ \\
\hline GFCF & $\begin{array}{l}0.23^{*} \\
(0.02)\end{array}$ & $\begin{array}{r}0.11 * * \\
(0.05)\end{array}$ & $0.22 *(0.02)$ & $0.11 * *(0.05)$ & $0.24 *(0.02)$ & $0.12(0.45)$ & $0.27 *(0.02)$ & $\begin{array}{l}0.06 \\
(0.04)\end{array}$ \\
\hline INF & $\begin{array}{l}-0.08^{*} \\
(0.01)\end{array}$ & $\begin{array}{r}-0.04 \\
(0.04)\end{array}$ & $\begin{array}{l}-0.08^{*} \\
(0.01)\end{array}$ & $\begin{array}{l}-0.04 \\
(0.04)\end{array}$ & $\begin{array}{l}-0.04 * \\
(0.01)\end{array}$ & $\begin{array}{l}-0.07 \\
(0.2)\end{array}$ & $\begin{array}{l}-0.1^{*} \\
(0.01)\end{array}$ & $\begin{array}{l}-0.01 \\
(0.03)\end{array}$ \\
\hline No. of observations & 495 & 495 & 495 & 495 & 495 & 495 & 495 & 495 \\
\hline $\begin{array}{l}\text { Hansen J-stat (p- } \\
\text { vale) }\end{array}$ & $\begin{array}{l}29.92 \\
(0.32)\end{array}$ & & $\begin{array}{l}58.25 \\
(0.46)\end{array}$ & 0.00 & $\begin{array}{l}30.54 \\
(0.25)\end{array}$ & & $\begin{array}{l}29.46 \\
(0.25)\end{array}$ & \\
\hline $\operatorname{AR}(1)$ & -1.27 & & $14.44 * *$ & $-1.62 * * *$ & -0.96 & & & \\
\hline $\operatorname{AR}(2)$ & 0.83 & & & 0.76 & 0.43 & & & \\
\hline
\end{tabular}

Note: $* * *$, and $* * *$ represents significance at $1 \%, 5 \%$ and $10 \%$ respectively. The coefficient of constant is ignored. Robust standard errors are in parenthesis. Hansen J-stat p-values are in parenthesis. 
Table 4. Growth equation's results 2001-2016 - Europe

\begin{tabular}{|c|c|c|c|c|c|c|c|c|}
\hline \multirow{3}{*}{$\begin{array}{l}\text { Explanatory } \\
\text { Variables }\end{array}$} & \multicolumn{8}{|c|}{ Europe Group-3 } \\
\hline & \multicolumn{2}{|r|}{1} & \multicolumn{2}{|c|}{2} & \multicolumn{2}{|c|}{3} & \multicolumn{2}{|c|}{4} \\
\hline & $G M M$ & $2 S L S$ & GMM & $2 S L S$ & GMM & $2 S L S$ & GMM & $2 S L S$ \\
\hline $\mathrm{GDPPCG}_{\mathrm{t}-1}$ & $\begin{array}{l}0.34^{*} \\
(0.07)\end{array}$ & & $\begin{array}{l}0.33^{*} \\
(0.1)\end{array}$ & & $\begin{array}{l}0.46^{*} \\
(0.14)\end{array}$ & & $\begin{array}{l}0.45^{* *} \\
(0.23)\end{array}$ & \\
\hline RERMIS & $\begin{array}{l}1.87 \\
(3.46)\end{array}$ & $\begin{array}{l}0.01 \\
(0.13)\end{array}$ & $\begin{array}{l}1.54 \\
(3.58)\end{array}$ & $\begin{array}{l}0.16 \\
(0.19)\end{array}$ & $\begin{array}{l}1.27 \\
(6.35)\end{array}$ & $\begin{array}{l}0.06 \\
(0.13)\end{array}$ & $\begin{array}{l}4.94 \\
(16.04)\end{array}$ & $\begin{array}{l}0.85 \\
(0.7)\end{array}$ \\
\hline \multicolumn{9}{|c|}{ Proxies for financial integration and interaction } \\
\hline $\begin{array}{l}\text { FDI } \\
\text { RERMIS*FDI }\end{array}$ & $\begin{array}{l}25.88^{*} \\
(5.62)\end{array}$ & $\begin{array}{l}7.42 \\
(5.23)\end{array}$ & $\begin{array}{l}1.91 \\
(14.28) \\
-70.69 * * \\
(33.53)\end{array}$ & $\begin{array}{l}3.27 \\
(3.07) \\
- \\
13.23 * \\
(4.23)\end{array}$ & $\begin{array}{l}13.52 \\
(18.68)\end{array}$ & $\begin{array}{l}7.42 \\
(4.81)\end{array}$ & $\begin{array}{l}20.99 \\
(16.2)\end{array}$ & $\begin{array}{l}7.15 \\
(4.82)\end{array}$ \\
\hline $\begin{array}{l}\text { FOPEN } \\
\text { RERMIS* FOPEN }\end{array}$ & & & & & $\begin{array}{l}16.41^{*} \\
(5.23)\end{array}$ & $\begin{array}{l}-1.26 * * \\
(0.59)\end{array}$ & $\begin{array}{l}-20.99 \\
(16.91) \\
-13.87 * * * \\
(3.85)\end{array}$ & $\begin{array}{l}-0.67 \\
(0.74) \\
-1.01 \\
(0.90)\end{array}$ \\
\hline \multicolumn{9}{|c|}{ Inclusion of control variables } \\
\hline GE & $\begin{array}{l}1.52^{*} \\
(0.19)\end{array}$ & $\begin{array}{l}0.18 * * \\
(0.09)\end{array}$ & $\begin{array}{l}1.39^{*} \\
(0.19)\end{array}$ & $\begin{array}{l}0.2 * * \\
(0.09)\end{array}$ & $\begin{array}{l}1.36 * * \\
(0.59)\end{array}$ & $\begin{array}{l}0.17 * * * \\
(0.1)\end{array}$ & $\begin{array}{l}1.09^{*} \\
(0.42)\end{array}$ & $\begin{array}{l}0.17 * * * \\
(0.1)\end{array}$ \\
\hline GFCF & $\begin{array}{l}0.22 * \\
(0.06)\end{array}$ & $\begin{array}{l}0.04 \\
(0.04)\end{array}$ & $\begin{array}{l}0.21^{* *} \\
(0.09)\end{array}$ & $\begin{array}{l}0.03 \\
(0.04)\end{array}$ & $\begin{array}{l}0.42 * * \\
(0.18)\end{array}$ & $\begin{array}{l}0.05 \\
(0.04)\end{array}$ & $\begin{array}{l}0.38^{* *} \\
(0.19)\end{array}$ & $\begin{array}{l}0.06 \\
(0.05)\end{array}$ \\
\hline INF & $\begin{array}{l}-0.19^{* *} \\
(0.1)\end{array}$ & $\begin{array}{l}-0.03 \\
(0.04)\end{array}$ & $\begin{array}{l}-0.16 \\
(0.11)\end{array}$ & $\begin{array}{l}-0.02 \\
(0.04)\end{array}$ & $\begin{array}{l}-0.5^{* *} \\
(0.21)\end{array}$ & $\begin{array}{l}-0.05 \\
(0.04)\end{array}$ & $\begin{array}{l}-0.48 \\
(0.32)\end{array}$ & $\begin{array}{l}-0.05 \\
(0.04)\end{array}$ \\
\hline No. of observations & 280 & 300 & 280 & 300 & 280 & 300 & 280 & 300 \\
\hline Hansen J-stat (p-vale) & $\begin{array}{l}18.36 \\
(0.19)\end{array}$ & & $\begin{array}{l}17.55 \\
(0.18)\end{array}$ & & $\begin{array}{l}13.87 \\
(0.38)\end{array}$ & & $\begin{array}{l}12.92 \\
(0.37)\end{array}$ & \\
\hline AR (1) & $-2.82 *$ & & $-1.85 * * *$ & & -0.11 & & -0.06 & \\
\hline $\operatorname{AR}(2)$ & $-1.91 * * *$ & & -0.31 & & -0.09 & & -0.04 & \\
\hline
\end{tabular}

Note: $* * *$, and $* * *$ represents significance at $1 \%, 5 \%$ and $10 \%$ respectively. The coefficient of constant is ignored. Robust standard errors are in parenthesis. Hansen J-stat p-values are in parenthesis. 
Table 5. Growth equation's results 2001-2016 - Africa

\begin{tabular}{|c|c|c|c|c|c|c|c|c|}
\hline \multirow{3}{*}{$\begin{array}{l}\text { Explanatory } \\
\text { Variables }\end{array}$} & \multicolumn{8}{|c|}{ Africa Group-4 } \\
\hline & \multicolumn{2}{|c|}{1} & \multicolumn{2}{|c|}{2} & \multicolumn{2}{|c|}{3} & \multicolumn{2}{|c|}{4} \\
\hline & GMM & $2 S L S$ & GMM & $2 S L S$ & GMM & $2 S L S$ & GMM & $2 S L S$ \\
\hline $\begin{array}{l}\text { GDPPCG }_{\mathrm{t}-1} \\
\text { RERMIS }\end{array}$ & $\begin{array}{l}-0.69 * \\
(0.08) \\
0.21 * * * \\
(0.06)\end{array}$ & $\begin{array}{r}0.15 * * \\
(0.06)\end{array}$ & $\begin{array}{l}-0.87 * * \\
(0.35) \\
2.5 \\
(2.26)\end{array}$ & $\begin{array}{r}1.01 \\
(0.92)\end{array}$ & $\begin{array}{l}-0.37 * \\
(0.13) \\
0.15 * * \\
(0.06)\end{array}$ & $\begin{array}{r}0.15 * * \\
(0.06)\end{array}$ & $\begin{array}{l}-0.58 \\
(0.39) \\
22.61 \\
(34.2)\end{array}$ & $\begin{array}{r}2.84 \\
(4.2)\end{array}$ \\
\hline \multicolumn{9}{|c|}{ Proxies for financial integration and interaction terms } \\
\hline $\begin{array}{l}\text { FDI } \\
\text { RERMIS*FDI }\end{array}$ & $\begin{array}{l}2.31 \\
(43.64)\end{array}$ & $\begin{array}{r}0.73 \\
(25.54)\end{array}$ & $\begin{array}{l}127.49 \\
(174.66) \\
-333.81 \\
(301.36)\end{array}$ & $\begin{array}{r}57.33 \\
(38.79) \\
-110.9 \\
(114.43)\end{array}$ & $\begin{array}{l}16.4 \\
(30.93)\end{array}$ & $\begin{array}{r}1.22 \\
(27.95)\end{array}$ & $\begin{array}{l}83.45 \\
(105.87)\end{array}$ & $\begin{array}{r}0.6 \\
(28.19)\end{array}$ \\
\hline $\begin{array}{l}\text { FOPEN } \\
\text { RERMIS* FOPEN } \\
\text { Inclusion of control } 1\end{array}$ & iables & & & & $\begin{array}{l}252.81 \\
(337.16)\end{array}$ & $\begin{array}{r}0.77 \\
(2.62)\end{array}$ & $\begin{array}{l}95.25 \\
(365.21) \\
-134.62 \\
(197.88)\end{array}$ & $\begin{array}{r}8.03 \\
(13.9) \\
-17.61 \\
(24.74)\end{array}$ \\
\hline $\begin{array}{l}\text { GE } \\
\text { GFCF } \\
\text { INF }\end{array}$ & $\begin{array}{l}1.53 * * * \\
(0.87) \\
0.15 \\
(0.4) \\
-0.11 \\
(0.28)\end{array}$ & $\begin{array}{r}0.18 \\
(0.21) \\
0.24^{*} \\
(0.07) \\
-0.12 \\
(0.25)\end{array}$ & $\begin{array}{l}3.28^{*} \\
(0.89) \\
0.28 \\
(0.62) \\
0.1 \\
(0.3)\end{array}$ & $\begin{array}{r}0.22 \\
(0.27) \\
0.25^{*} \\
(0.07) \\
-0.14 \\
(0.27)\end{array}$ & $\begin{array}{l}1.37 * * \\
(0.63) \\
0.07 \\
(0.18) \\
0.22 \\
(0.17)\end{array}$ & $\begin{array}{r}0.17 \\
(0.2) \\
0.25^{*} \\
(0.05) \\
-0.12 \\
(0.26)\end{array}$ & $\begin{array}{l}1.26 \\
(1.27) \\
-0.23 \\
(0.45) \\
0.09 \\
(0.31)\end{array}$ & $\begin{array}{r}0.18 \\
(0.2) \\
0.25^{*} \\
(0.05) \\
-0.12 \\
(0.26)\end{array}$ \\
\hline $\begin{array}{l}\text { No. of observations } \\
\text { Hansen J-stat (p-vale) }\end{array}$ & $\begin{array}{l}112 \\
4.1 \\
(0.13)\end{array}$ & 112 & $\begin{array}{l}112 \\
2.77 \\
(0.1)\end{array}$ & 112 & $\begin{array}{l}112 \\
0.28 \\
(0.59)\end{array}$ & 112 & $\begin{array}{l}112 \\
1.63 \\
(0.49)\end{array}$ & 112 \\
\hline $\begin{array}{l}\operatorname{AR}(1) \\
\operatorname{AR}(2)\end{array}$ & -0.3 & & -0.06 & & -0.35 & & -0.45 & \\
\hline
\end{tabular}

Note: $* * *$, and $* * *$ represents significance at $1 \%, 5 \%$ and $10 \%$ respectively. The coefficient of constant is ignored. Robust standard errors are in parenthesis. Hansen J-stat p-values are in parenthesis. 
Table 6. Growth equation's results 2001-2016 - specifications with inward FDI stock

\begin{tabular}{|c|c|c|c|c|c|c|c|c|}
\hline \multirow{3}{*}{$\begin{array}{l}\text { Explanatory } \\
\text { Variables }\end{array}$} & \multicolumn{8}{|c|}{ Global Group-1 } \\
\hline & \multicolumn{2}{|c|}{1} & \multicolumn{2}{|c|}{2} & \multicolumn{2}{|c|}{3} & \multicolumn{2}{|c|}{4} \\
\hline & GMM & $2 S L S$ & GMM & $2 S L S$ & GMM & $2 S L S$ & GMM & $2 S L S$ \\
\hline $\begin{array}{l}\text { GDPPCG }_{\mathrm{t}-1} \\
\text { RERMIS }\end{array}$ & $\begin{array}{l}-0.21^{*} \\
(0.01) \\
-0.27^{*} \\
(0.02)\end{array}$ & $\begin{array}{l}0.05^{*} \\
(0.02)\end{array}$ & $\begin{array}{l}-0.21 * \\
(0.01) \\
0.04 \\
(0.09)\end{array}$ & $\begin{array}{r}0.1 \\
(0.07)\end{array}$ & $\begin{array}{l}-0.22^{*} \\
(0.01) \\
-0.26^{*} \\
(0.03)\end{array}$ & $\begin{array}{r}0.03 \\
(0.02)\end{array}$ & $\begin{array}{l}-0.22^{*} \\
(0.01) \\
-0.06 \\
(0.06)\end{array}$ & $\begin{array}{r}0.02 \\
(0.02)\end{array}$ \\
\hline \multicolumn{9}{|c|}{ Proxies for financial integration and interaction terms } \\
\hline $\begin{array}{l}\text { FDI stock } \\
\text { RERMIS*FDI stock }\end{array}$ & $\begin{array}{l}8.08 * \\
(0.38)\end{array}$ & $\begin{array}{l}0.08 \\
(0.08)\end{array}$ & $\begin{array}{l}7.2^{*} \\
(0.48) \\
-0.81 * * \\
(0.41)\end{array}$ & $\begin{array}{r}0.01 \\
(0.14) \\
-0.17 \\
(0.22)\end{array}$ & $\begin{array}{l}8.2^{*} \\
(0.69)\end{array}$ & $\begin{array}{r}0.14 * * * \\
(0.08)\end{array}$ & $\begin{array}{l}9.21 * \\
(0.78)\end{array}$ & $\begin{array}{r}0.14 * * * \\
(0.08)\end{array}$ \\
\hline $\begin{array}{l}\text { FOPEN } \\
\text { RERMIS* FOPEN } \\
\text { Inclusion of control va }\end{array}$ & iables & & & & $\begin{array}{l}18.05^{*} \\
(1.37)\end{array}$ & $\begin{array}{r}1.84 * * \\
(0.91)\end{array}$ & $\begin{array}{l}18.12^{*} \\
(1.57) \\
-0.65^{*} \\
(0.1)\end{array}$ & $\begin{array}{r}1.88 * * \\
(0.89) \\
-0.09 * * \\
(0.04)\end{array}$ \\
\hline GE & $\begin{array}{l}-0.84 * \\
(0.02)\end{array}$ & $\begin{array}{l}-0.11 \\
(0.07)\end{array}$ & $\begin{array}{l}-0.85^{*} \\
(0.03)\end{array}$ & $\begin{array}{r}-0.1 \\
(0.07)\end{array}$ & $\begin{array}{l}-0.89 * \\
(0.03)\end{array}$ & $\begin{array}{r}-0.07 \\
(0.07)\end{array}$ & $\begin{array}{l}-1.05^{*} \\
(0.05)\end{array}$ & $\begin{array}{r}-0.07 \\
(0.07)\end{array}$ \\
\hline GFCF & $\begin{array}{l}0.29 * \\
(0.01)\end{array}$ & $\begin{array}{l}0.17 * \\
(0.06)\end{array}$ & $\begin{array}{l}0.29 * \\
(0.01)\end{array}$ & $\begin{array}{l}0.17^{*} \\
(0.06)\end{array}$ & $\begin{array}{l}0.3 * \\
(0.01)\end{array}$ & $\begin{array}{l}0.16^{*} \\
(0.06)\end{array}$ & $\begin{array}{l}0.31 * \\
(0.01)\end{array}$ & $\begin{array}{c}0.16^{*} \\
(0.06)\end{array}$ \\
\hline INF & $\begin{array}{l}0.05^{*} \\
(0.01)\end{array}$ & $\begin{array}{l}0.02 \\
(0.04)\end{array}$ & $\begin{array}{l}0.05^{*} \\
(0.01)\end{array}$ & $\begin{array}{r}0.02 \\
(0.04)\end{array}$ & $\begin{array}{l}0.08^{*} \\
(0.01)\end{array}$ & $\begin{array}{r}0.01 \\
(0.04) \\
\end{array}$ & $\begin{array}{l}0.06^{*} \\
(0.01)\end{array}$ & $0(0.04)$ \\
\hline $\begin{array}{l}\text { No. of observations } \\
\text { Hansen J-stat (p-vale) } \\
\text { AR (1) } \\
\text { AR (2) }\end{array}$ & $\begin{array}{l}910 \\
63.51 \\
(0.32) \\
-1.28 \\
-3.14^{*}\end{array}$ & 910 & $\begin{array}{l}910 \\
62.04 \\
(0.33) \\
-1.28 \\
-3.31 *\end{array}$ & 910 & $\begin{array}{l}910 \\
59.1 \\
(0.44) \\
-1.28 \\
-3.33^{*}\end{array}$ & & $\begin{array}{l}910 \\
58.4 \\
(0.42) \\
-1 \\
-0.64\end{array}$ & 910 \\
\hline
\end{tabular}

Note: $* * *$, and $* * *$ represents significance at $1 \%, 5 \%$ and $10 \%$ respectively. The coefficient of constant is ignored. Robust standard errors are in parenthesis. Hansen J-stat p-values are in parenthesis. 
Table 7. Growth equation's results 2013-2016 - All BRI countries

\begin{tabular}{|c|c|c|c|c|c|c|c|c|}
\hline \multirow{2}{*}{$\begin{array}{l}\text { Explanatory } \\
\text { Variables }\end{array}$} & \multicolumn{8}{|c|}{ Global Group-I } \\
\hline & GMM & $2 S L S$ & GMM & $2 S L S$ & GMM & $2 S L S$ & GMM & $2 S L S$ \\
\hline $\mathrm{GDPPCG}_{\mathrm{t}-1}$ & $\begin{array}{l}0.38 * \\
(0.00)\end{array}$ & & $\begin{array}{l}0.38 * \\
(0.00)\end{array}$ & & $\begin{array}{l}-0.38^{*} \\
(0.01)\end{array}$ & & $\begin{array}{l}- \\
0.38 *(0)\end{array}$ & \\
\hline RERMIS & $\begin{array}{l}0.55^{* *} \\
(0.08)\end{array}$ & $\begin{array}{r}0.05 * * \\
(0.02)\end{array}$ & $\begin{array}{l}2.24 * \\
(0.11)\end{array}$ & $\begin{array}{r}0.09 * * * \\
(0.06)\end{array}$ & $\begin{array}{c}0.55^{*} \\
(0.08)\end{array}$ & $\begin{array}{r}0.35 \\
(0.81)\end{array}$ & $\begin{array}{l}1.27^{*} \\
(0.13)\end{array}$ & $\begin{array}{r}0.4 \\
(0.92)\end{array}$ \\
\hline \multicolumn{9}{|c|}{ Proxies for financial integration and interaction terms } \\
\hline $\begin{array}{l}\text { FDI } \\
\text { RERMIS*FDI }\end{array}$ & $\begin{array}{l}2.78 \\
(3.13)\end{array}$ & $\begin{array}{r}9.78 \\
(9.00)\end{array}$ & $\begin{array}{c}1.05 * * * \\
(4.12) \\
-2.44 * * * \\
(1.70)\end{array}$ & $\begin{array}{r}1.44 * * \\
(9.46) \\
-1.60 \\
(1.21)\end{array}$ & $\begin{array}{l}1.71 \\
(0.83)\end{array}$ & $\begin{array}{r}7.57 \\
(7.67)\end{array}$ & $\begin{array}{c}2.71 * * \\
(5.83)\end{array}$ & $\begin{array}{r}1.57 * * * \\
(5.67)\end{array}$ \\
\hline FOPEN & & & & & $\begin{array}{l}1.85 \\
(2.08)\end{array}$ & $\begin{array}{r}11.97 \\
(34.17)\end{array}$ & $\begin{array}{l}1.45 \\
(2.08)\end{array}$ & $\begin{array}{r}12.05 \\
(34.69)\end{array}$ \\
\hline $\begin{array}{l}\text { RERMIS* } \\
\text { FOPEN } \\
\text { Inclusion of control }\end{array}$ & variables & & & & & & $\begin{array}{l}-0.94^{*} \\
(0.08)\end{array}$ & $\begin{array}{r}-1.31 * * * \\
(0.85)\end{array}$ \\
\hline $\mathrm{GE}$ & $\begin{array}{l}1.18^{*} \\
(0.09)\end{array}$ & $\begin{array}{r}0.14 * * \\
(0.06)\end{array}$ & $\begin{array}{c}1.12 * * * \\
(0.07)\end{array}$ & $\begin{array}{l}0.14^{*} \\
(0.06)\end{array}$ & $\begin{array}{l}1.19 * \\
(0.09)\end{array}$ & $\begin{array}{r}1.95 \\
(4.64)\end{array}$ & $\begin{array}{l}0.38^{*} \\
(0.04)\end{array}$ & $\begin{array}{r}1.95 \\
(4.69)\end{array}$ \\
\hline GFCF & $\begin{array}{l}0.40 * * * \\
(0.02)\end{array}$ & $\begin{array}{r}0.20 * * \\
(0.11)\end{array}$ & $\begin{array}{c}0.32^{* * *} \\
(0.03)\end{array}$ & $\begin{array}{l}0.20^{*} \\
(0.11)\end{array}$ & $\begin{array}{l}0.4^{*} \\
(0.03)\end{array}$ & $\begin{array}{r}1.06 \\
(2.52)\end{array}$ & $\begin{array}{l}0.37^{*} \\
(0.03)\end{array}$ & $\begin{array}{r}1.07 \\
(2.56)\end{array}$ \\
\hline INF & $\begin{array}{r}-0.32 * \\
(0.02)\end{array}$ & $\begin{array}{r}-0.17 * \\
(0.05)\end{array}$ & $\begin{array}{c}-0.29 * * * \\
(0.20)\end{array}$ & $\begin{array}{l}-0.16 \\
(0.04)\end{array}$ & $\begin{array}{l}-0.33^{*} \\
(0.02)\end{array}$ & $\begin{array}{r}-1.47 \\
(3.95)\end{array}$ & $\begin{array}{l}-1.3^{*} \\
(0.24)\end{array}$ & $\begin{array}{r}-1.49 \\
(4.04)\end{array}$ \\
\hline $\begin{array}{l}\text { No. of observations } \\
\text { Hansen J-stat (p- } \\
\text { vale) } \\
\text { AR (1) } \\
\text { AR (2) }\end{array}$ & $\begin{array}{l}260 \\
63.76 \\
(0.31) \\
25.13^{*}\end{array}$ & $\begin{array}{r} \\
-2.14^{* *} \\
0.82\end{array}$ & $\begin{array}{l}260 \\
44.26 \\
(0.41) \\
14.44 * *\end{array}$ & $\begin{array}{r}-1.62 * * * \\
0.76\end{array}$ & $\begin{array}{l}260 \\
46.57 \\
(0.33) \\
1.12 \\
-1.26 * * *\end{array}$ & 260 & $\begin{array}{l}260 \\
43.04 \\
(0.43)\end{array}$ & 260 \\
\hline
\end{tabular}

Note: $* * *$, and $* * *$ represents significance at $1 \%, 5 \%$ and $10 \%$ respectively. The coefficient of constant is ignored. Robust standard errors are in parenthesis. Hansen J-stat p-values are in parenthesis. 
Table 8. Growth equation's results 2013-2016 - Asia

\begin{tabular}{|c|c|c|c|c|c|c|c|c|}
\hline \multirow{3}{*}{$\begin{array}{l}\text { Explanatory } \\
\text { Variables }\end{array}$} & \multicolumn{8}{|c|}{ Asia Group-2 } \\
\hline & \multicolumn{2}{|c|}{1} & \multicolumn{2}{|c|}{2} & \multicolumn{2}{|c|}{3} & \multicolumn{2}{|c|}{4} \\
\hline & $G M M$ & $2 S L S$ & GMM & $2 S L S$ & GMM & $2 S L S$ & GMM & $2 S L S$ \\
\hline $\mathrm{GDPPCG}_{\mathrm{t}-1}$ & $\begin{array}{l}0.42 * \\
(0.03)\end{array}$ & & $\begin{array}{l}0.44^{*} \\
(0.03)\end{array}$ & & $\begin{array}{l}0.42 * \\
(0.03)\end{array}$ & & $\begin{array}{l}0.42 * \\
(0.03)\end{array}$ & \\
\hline RERMIS & $\begin{array}{l}0.1^{*} \\
(0.02)\end{array}$ & $\begin{array}{r}0.02 \\
(0.01)\end{array}$ & $\begin{array}{l}0.01 \\
(0.05)\end{array}$ & $\begin{array}{l}-0.03 \\
(0.05)\end{array}$ & $\begin{array}{l}0.09 * * * \\
(0.05)\end{array}$ & $\begin{array}{r}0.02 \\
(0.02)\end{array}$ & $\begin{array}{l}0.02 \\
(0.22)\end{array}$ & $\begin{array}{r}0.01 \\
(0.02)\end{array}$ \\
\hline \multicolumn{9}{|c|}{ Proxies for financial integration and interaction terms } \\
\hline $\begin{array}{l}\text { FDI } \\
\text { RERMIS*FDI }\end{array}$ & $\begin{array}{l}6.74 * * * \\
(3.82)\end{array}$ & $\begin{array}{r}3.13 \\
(3)\end{array}$ & $\begin{array}{l}2.51 \\
(5.41) \\
-2.03 * * * \\
(1.24)\end{array}$ & $\begin{array}{r}4.46 \\
(4.44) \\
-0.6 \\
(0.84)\end{array}$ & $\begin{array}{l}0.14 \\
(4.42)\end{array}$ & $\begin{array}{r}6.28 * * * \\
(3.4)\end{array}$ & $\begin{array}{l}1.99 \\
(4.99)\end{array}$ & $\begin{array}{r}6.88 * * \\
(3.41)\end{array}$ \\
\hline $\begin{array}{l}\text { FOPEN } \\
\text { RERMIS* } \\
\text { FOPEN } \\
\text { Inclusion of cor }\end{array}$ & . & & & & $\begin{array}{l}4.97 \\
(3.28)\end{array}$ & $\begin{array}{l}2.41^{*} \\
(0.88)\end{array}$ & $\begin{array}{l}3.73 \\
(3.46) \\
-1.12 * * * \\
(0.07)\end{array}$ & $\begin{array}{l}2.58^{*} \\
(0.91) \\
-0.14^{*} \\
(0.06)\end{array}$ \\
\hline GE & $\begin{array}{l}0.01 \\
(0.07)\end{array}$ & $\begin{array}{r}0.09 * * * \\
(0.05)\end{array}$ & $\begin{array}{l}0.01 \\
(0.09)\end{array}$ & $\begin{array}{r}0.08 * * * \\
(0.05)\end{array}$ & $\begin{array}{l}0.02 \\
(0.06)\end{array}$ & $\begin{array}{r}0.04 \\
(0.05)\end{array}$ & $\begin{array}{l}0.04 \\
(0.06)\end{array}$ & $\begin{array}{r}0.04 \\
(0.05)\end{array}$ \\
\hline GFCF & $\begin{array}{l}-0.51^{*} \\
(0.02)\end{array}$ & $\begin{array}{r}0.16 \\
(0.1)\end{array}$ & $\begin{array}{l}-0.5^{*} \\
(0.02)\end{array}$ & $\begin{array}{r}0.16 \\
(0.1)\end{array}$ & $\begin{array}{l}-0.5^{*} \\
(0.02)\end{array}$ & $\begin{array}{r}0.13 \\
(0.09)\end{array}$ & $\begin{array}{l}-0.49^{*} \\
(0.02)\end{array}$ & $\begin{array}{r}0.14 \\
(0.09)\end{array}$ \\
\hline INF & $\begin{array}{l}0.06^{* *} \\
(0.03)\end{array}$ & $\begin{array}{r}-0.01 \\
(0.06)\end{array}$ & $\begin{array}{l}0.04 * * * \\
(0.02)\end{array}$ & $\begin{array}{r}-0.01 \\
(0.06)\end{array}$ & $\begin{array}{l}-0.06 * * * \\
(0.03)\end{array}$ & $\begin{array}{r}-0.05 \\
(0.07)\end{array}$ & $\begin{array}{l}-0.04 * * * \\
(0.02)\end{array}$ & $\begin{array}{r}-0.05 \\
(0.07)\end{array}$ \\
\hline $\begin{array}{l}\text { No. of } \\
\text { observations } \\
\text { Hansen J-stat } \\
\text { (p-vale) } \\
\text { AR (1) } \\
\text { AR (2) }\end{array}$ & $\begin{array}{l}132 \\
25.86 \\
(0.53)\end{array}$ & 132 & $\begin{array}{l}132 \\
26.4 \\
(0.44) \\
-1.04\end{array}$ & 132 & $\begin{array}{l}132 \\
21.66(0.71) \\
-1.27\end{array}$ & 132 & $\begin{array}{l}132 \\
19.25 \\
(0.78) \\
-0.72 \\
-0.13\end{array}$ & 132 \\
\hline
\end{tabular}

Note: $* * *$, and $* * *$ represents significance at $1 \%, 5 \%$ and $10 \%$ respectively. The coefficient of constant is ignored. Robust standard errors are in parenthesis. Hansen J-stat p-values are in parenthesis. 
Table 9. Growth equation's results 2013-2016 - Europe

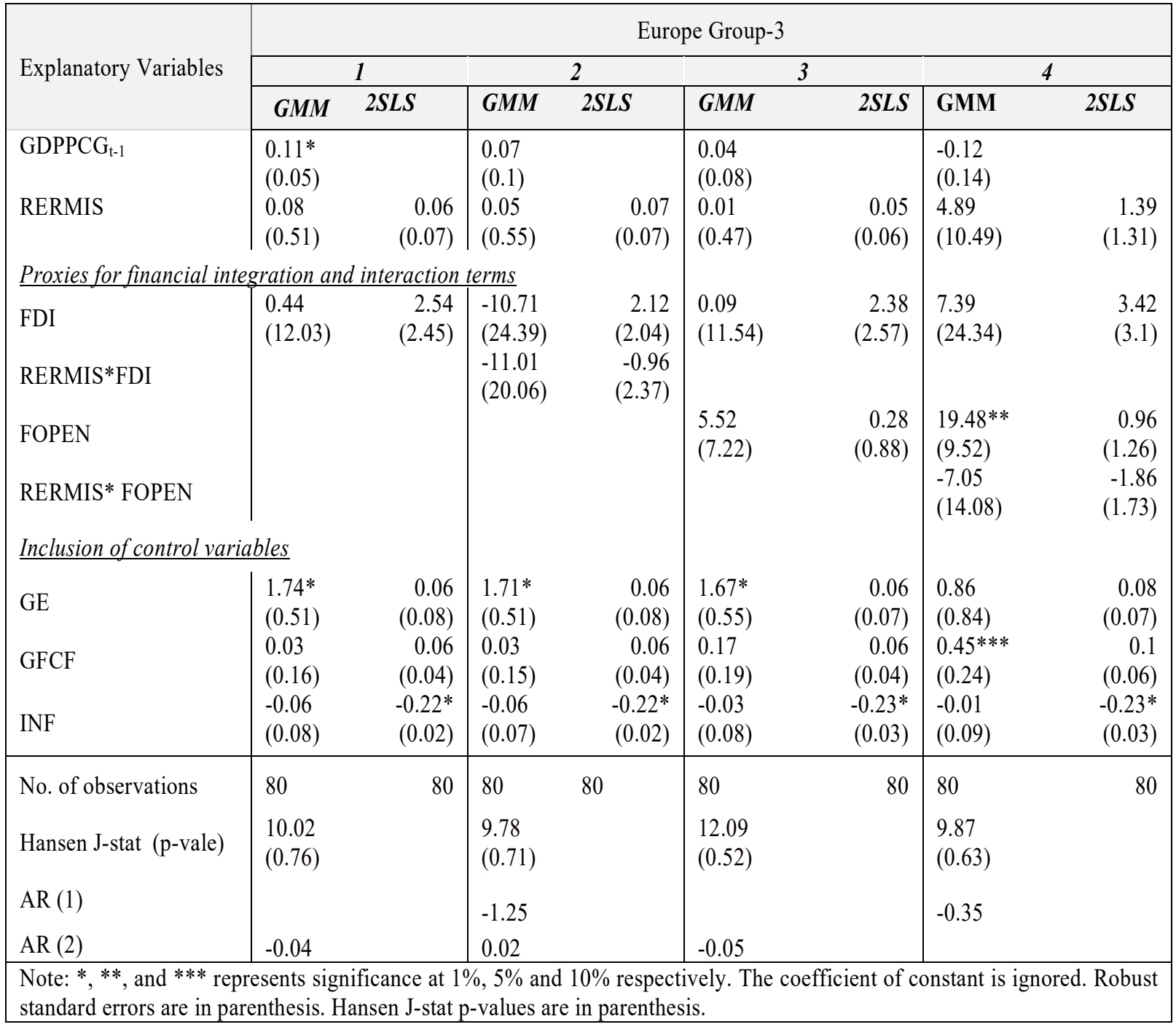


Table 10. Growth equation's results 2013-2016 - Africa

\begin{tabular}{|c|c|c|c|c|c|c|c|c|}
\hline \multirow{3}{*}{ Explanatory Variables } & \multicolumn{8}{|c|}{ Africa Group-4 } \\
\hline & \multicolumn{2}{|c|}{1} & \multicolumn{2}{|c|}{2} & \multicolumn{2}{|c|}{3} & \multicolumn{2}{|c|}{4} \\
\hline & GMM & $2 S L S$ & GMM & $2 S L S$ & GMM & $2 S L S$ & GMM & $2 S L S$ \\
\hline $\mathrm{GDPPCG}_{\mathrm{t}-1}$ & $\begin{array}{l}-0.45^{*} \\
(0.01)\end{array}$ & & $\begin{array}{l}-0.37^{*} \\
(0.02)\end{array}$ & & $\begin{array}{l}-0.54^{*} \\
(0.01)\end{array}$ & & $\begin{array}{l}-1.33^{*} \\
(0.13)\end{array}$ & \\
\hline RERMIS & $\begin{array}{l}30.58^{*} \\
(0.95)\end{array}$ & $\begin{array}{l}7.53^{*} \\
(2.05)\end{array}$ & $\begin{array}{l}187.19^{*} \\
(47.27)\end{array}$ & $\begin{array}{l}67.02 * \\
(19.45)\end{array}$ & $\begin{array}{l}5.19^{*} \\
(0.42)\end{array}$ & $\begin{array}{l}7.47^{*} \\
(2.32)\end{array}$ & $\begin{array}{l}99.8 \\
(106.2)\end{array}$ & $\begin{array}{r}55.58 \\
(99.78)\end{array}$ \\
\hline \multicolumn{9}{|c|}{ Proxies for financial integration and interaction terms } \\
\hline $\begin{array}{l}\text { FDI } \\
\text { RERMIS*FDI }\end{array}$ & $\begin{array}{l}18.12 \\
(66.88)\end{array}$ & $\begin{array}{r}48.87 \\
(52.83)\end{array}$ & $\begin{array}{l}127.18 * * \\
(57.4) \\
-2854.14 * \\
(978.69)\end{array}$ & $\begin{array}{r}65.15^{*} \\
(22.41) \\
-1224.68^{*} \\
(397.28)\end{array}$ & $\begin{array}{l}11.74 \\
(44.97)\end{array}$ & $\begin{array}{r}46.59 \\
(48.75)\end{array}$ & $\begin{array}{l}81.11 \\
(80.85)\end{array}$ & $\begin{array}{r}31.89 \\
(45.42)\end{array}$ \\
\hline $\begin{array}{l}\text { FOPEN } \\
\text { RERMIS* FOPEN }\end{array}$ & & & & & $\begin{array}{l}0.27 \\
(1.58)\end{array}$ & $\begin{array}{r}2.52 \\
(10.45)\end{array}$ & $\begin{array}{l}16.46 \\
(25.63) \\
-2.02 * * * \\
(0.09)\end{array}$ & $\begin{array}{r}14.6 \\
(23.21) \\
-0.25^{*} \\
(0.06)\end{array}$ \\
\hline \multicolumn{9}{|c|}{ Inclusion of control variables } \\
\hline GE & $\begin{array}{l}0.26 \\
(0.56)\end{array}$ & $\begin{array}{r}0.23 \\
(0.21)\end{array}$ & $\begin{array}{l}0.89 \\
(0.96)\end{array}$ & $\begin{array}{l}0.92 * \\
(0.34)\end{array}$ & $\begin{array}{l}0.83^{*} \\
(0.19)\end{array}$ & $\begin{array}{l}0.25 \\
(0.3)\end{array}$ & $\begin{array}{l}35.38 \\
(23.22)\end{array}$ & $\begin{array}{r}0.26 \\
(0.29)\end{array}$ \\
\hline GFCF & $\begin{array}{l}0.03 \\
(0.31)\end{array}$ & $\begin{array}{r}0.19 \\
(0.13)\end{array}$ & $\begin{array}{l}0.28 \\
(0.55)\end{array}$ & $\begin{array}{r}0.08 \\
(0.06)\end{array}$ & $\begin{array}{l}0.03 \\
(0.14)\end{array}$ & $\begin{array}{r}0.2 \\
(0.14)\end{array}$ & $\begin{array}{l}18.3^{* * *} \\
(10.72)\end{array}$ & $\begin{array}{r}0.22 * * * \\
(0.13)\end{array}$ \\
\hline INF & $\begin{array}{l}0.15 \\
(0.2) \\
\end{array}$ & $\begin{array}{r}0.1 \\
(0.23) \\
\end{array}$ & $\begin{array}{l}0.01 \\
(0.13)\end{array}$ & $\begin{array}{r}0.06 \\
(0.28) \\
\end{array}$ & $\begin{array}{l}0.02 \\
(0.1)\end{array}$ & $\begin{array}{r}0.12 \\
(0.25) \\
\end{array}$ & $\begin{array}{l}-35.11 * \\
(9.62)\end{array}$ & $\begin{array}{r}0.24 \\
(0.33) \\
\end{array}$ \\
\hline $\begin{array}{l}\text { No. of observations } \\
\text { Hansen J-stat (p-vale) } \\
\text { AR (1) } \\
\text { AR (2) }\end{array}$ & $\begin{array}{l}32 \\
1.35 \\
(0.25)\end{array}$ & 32 & $\begin{array}{l}32 \\
1.97 \\
(0.16)\end{array}$ & 32 & $\begin{array}{l}32 \\
1.29 \\
(0.26)\end{array}$ & 32 & $\begin{array}{l}32 \\
1.88 \\
(0.24)\end{array}$ & 32 \\
\hline
\end{tabular}

Note: $* * *$, and $* * *$ represents significance at $1 \%, 5 \%$ and $10 \%$ respectively. The coefficient of constant is ignored. Robust standard errors are in parenthesis. Hansen J-stat p-values are in parenthesis. 
Table 11. Growth equation's results 2013-2016 (all BRI countries) - specifications with inward FDI stock

\begin{tabular}{|c|c|c|c|c|c|c|c|c|}
\hline \multirow{3}{*}{ Explanatory Variables } & \multicolumn{8}{|c|}{ Global Group-1 } \\
\hline & \multicolumn{2}{|c|}{1} & \multicolumn{2}{|c|}{2} & \multicolumn{2}{|c|}{3} & \multicolumn{2}{|c|}{4} \\
\hline & $G M M$ & $2 S L S$ & GMM & $2 S L S$ & GMM & $2 S L S$ & GMM & $2 S L S$ \\
\hline $\mathrm{GDPPCG}_{\mathrm{t}-1}$ & $\begin{array}{l}-0.38^{*} \\
(0.01)\end{array}$ & & $\begin{array}{l}-0.38^{*} \\
(0.02)\end{array}$ & & $\begin{array}{l}-0.38^{*} \\
(0.01)\end{array}$ & & $\begin{array}{l}-0.39 * \\
(0.02)\end{array}$ & \\
\hline RERMIS & $\begin{array}{l}0.67 * \\
(0.04)\end{array}$ & $\begin{array}{l}0.06^{*} \\
(0.02)\end{array}$ & $\begin{array}{l}-0.23 * * * \\
(0.12)\end{array}$ & $\begin{array}{r}-0.07 \\
(0.07)\end{array}$ & $\begin{array}{l}-0.69^{*} \\
(0.05)\end{array}$ & $\begin{array}{r}0.04 \\
(0.03)\end{array}$ & $\begin{array}{l}-1.62 * \\
(0.12)\end{array}$ & $\begin{array}{r}0.05 * * \\
(0.03)\end{array}$ \\
\hline \multicolumn{9}{|c|}{ Proxies for financial integration and interaction terms } \\
\hline $\begin{array}{l}\text { FDI stock } \\
\text { RERMIS*FDI stock }\end{array}$ & $\begin{array}{l}8.6^{*} \\
(1.24)\end{array}$ & $\begin{array}{r}0.06 \\
(0.16)\end{array}$ & $\begin{array}{l}9.79 * \\
(1.56) \\
-0.94 * \\
(0.35)\end{array}$ & $\begin{array}{r}0.23 \\
(0.15) \\
-0.39^{* *} \\
(0.19)\end{array}$ & $\begin{array}{l}7.83 * \\
(1.51)\end{array}$ & $\begin{array}{r}0.09 \\
(0.14)\end{array}$ & $\begin{array}{l}9.42^{*} \\
(1.49)\end{array}$ & $\begin{array}{r}0.09 \\
(0.14)\end{array}$ \\
\hline FOPEN & & & & & $\begin{array}{l}1.34 * * * \\
(0.99)\end{array}$ & $\begin{array}{r}1.53 * * \\
(1.2)\end{array}$ & $\begin{array}{l}3.25 \\
(2.36)\end{array}$ & $\begin{array}{r}1.53 \\
(1.2)\end{array}$ \\
\hline $\begin{array}{l}\text { RERMIS* FOPEN } \\
\text { Inclusion of control vart }\end{array}$ & les & & & & & & $\begin{array}{l}-1.75^{*} \\
(0.27)\end{array}$ & $\begin{array}{r}- \\
0.23)^{* * *} \\
(0.11)\end{array}$ \\
\hline (2) & $-1.51 *$ & $-0.15 * *$ & $-1.56^{*}$ & $-0.16^{* *}$ & $-1.45 *$ & $-0.13 * *$ & $-1.19 *$ & $-0.12 * *$ \\
\hline UE & $(0.09)$ & $(0.06)$ & $(0.09)$ & $(0.06)$ & $(0.12)$ & $(0.06)$ & $(0.15)$ & $(0.06)$ \\
\hline GFCF & $-0.38 *$ & $0.2 * *$ & $-0.38 *$ & $0.21 * *$ & $-0.39 *$ & $0.19 * *$ & $-0.36^{*}$ & $0.19 * *$ \\
\hline GFCF & $(0.03)$ & $(0.1)$ & $(0.03)$ & $(0.1)$ & $(0.03)$ & $(0.09)$ & $(0.04)$ & $(0.09)$ \\
\hline INF & $-0.34 *$ & $-0.17 *$ & $-0.33 *$ & $-0.18^{*}$ & $-0.35 *$ & $-0.21^{*}$ & $-0.37 *$ & $-0.21 *$ \\
\hline & $(0.02)$ & $(0.05)$ & $(0.02)$ & $(0.05)$ & $(0.03)$ & $(0.06)$ & $(0.04)$ & $(0.06)$ \\
\hline No. of observations & 260 & 260 & 260 & 60 & 260 & 260 & 260 & 260 \\
\hline Hansen J-stat (p-vale) & $\begin{array}{l}44.32 \\
(0.46)\end{array}$ & & $\begin{array}{l}44.95 \\
(0.39)\end{array}$ & & $\begin{array}{l}43.07 \\
(0.47)\end{array}$ & & $\begin{array}{l}39.45 \\
(058)\end{array}$ & \\
\hline AR (1) & 1.19 & & 1.18 & & 1.18 & & 1.3 & \\
\hline $\operatorname{AR}(2)$ & -1.25 & & -1.17 & & -1.25 & & -1.1 & \\
\hline
\end{tabular}

Note: $* * *$, and $* * *$ represents significance at $1 \%, 5 \%$ and $10 \%$ respectively. The coefficient of constant is ignored. Robust standard errors are in parenthesis. Hansen J-stat p-values are in parenthesis. 
Table 12. Growth equation's results 2009-2016 (all BRI countries)- specification with time dummy

\begin{tabular}{|c|c|c|c|c|c|c|c|c|}
\hline \multirow{3}{*}{ Explanatory Variables } & \multicolumn{8}{|c|}{ Global Group-1 } \\
\hline & \multicolumn{2}{|c|}{1} & \multicolumn{2}{|c|}{2} & \multicolumn{2}{|c|}{3} & \multicolumn{2}{|c|}{4} \\
\hline & $R E$ & $F E$ & $R E$ & $F E$ & $R E$ & $F E$ & $R E$ & $F E$ \\
\hline RERMIS & $\begin{array}{l}0.18 * * * \\
(0.06)\end{array}$ & $\begin{array}{r}0.14 * * * \\
(0.07)\end{array}$ & $\begin{array}{l}0.11 \\
(0.11)\end{array}$ & $\begin{array}{r}0.049 \\
(0.147)\end{array}$ & $\begin{array}{l}0.04 \\
(0.07)\end{array}$ & $\begin{array}{r}0.06 \\
(0.12)\end{array}$ & $\begin{array}{l}0.15 * * * \\
(0.04)\end{array}$ & $\begin{array}{l}0.09 \\
(0.1)\end{array}$ \\
\hline \multicolumn{9}{|c|}{ Proxies for financial integration and interaction terms } \\
\hline $\begin{array}{l}\text { FDI } \\
\text { RERMIS*FDI }\end{array}$ & $\begin{array}{l}4.73 \\
(6.29)\end{array}$ & $\begin{array}{r}9.6 \\
(8.51)\end{array}$ & $\begin{array}{l}4.41 \\
(6.39) \\
-0.66 \\
(2.25)\end{array}$ & $\begin{array}{r}9.28 \\
(8.98) \\
-0.29 \\
(2.62)\end{array}$ & $\begin{array}{l}8.5 \\
(6.41)\end{array}$ & $\begin{array}{r}9.44 \\
(8.53)\end{array}$ & $\begin{array}{l}8.45 \\
(6.42)\end{array}$ & $\begin{array}{r}9.62 \\
(8.54)\end{array}$ \\
\hline $\begin{array}{l}\text { FOPEN } \\
\text { RERMIS* FOPEN } \\
\text { Inclusion of dummy var }\end{array}$ & & & & & $\begin{array}{l}-2.81^{*} \\
(1.06)\end{array}$ & $\begin{array}{l}-2.01 \\
(4.05)\end{array}$ & $\begin{array}{l}-2.82 * \\
(1.06) \\
-1.92 * * * \\
(0.08)\end{array}$ & $\begin{array}{r}-1.97 \\
(4.06) \\
-0.35^{*} \\
(0.06)\end{array}$ \\
\hline Dummy & $\begin{array}{l}0.23 * * * \\
(0.09)\end{array}$ & $\begin{array}{r}0.13^{* * * *} \\
(0.09)\end{array}$ & $\begin{array}{l}0.20 \\
(0.22)\end{array}$ & $\begin{array}{r}0.12 \\
(0.15)\end{array}$ & $\begin{array}{l}0.31 \\
(0.46)\end{array}$ & $\begin{array}{r}0.15 \\
(0.25)\end{array}$ & $\begin{array}{l}0.30^{* *} \\
(0.19)\end{array}$ & $\begin{array}{r}0.18 * * * \\
(0.10)\end{array}$ \\
\hline \multicolumn{9}{|c|}{ Inclusion of control variables } \\
\hline GE & $\begin{array}{l}0.24 * \\
(0.08)\end{array}$ & $\begin{array}{r}0.61 * * \\
(0.27)\end{array}$ & $\begin{array}{l}0.24^{*} \\
(0.08)\end{array}$ & $\begin{array}{r}0.60 * * \\
(0.26)\end{array}$ & $\begin{array}{l}0.2^{*} \\
(0.08)\end{array}$ & $\begin{array}{r}0.61 * * \\
(0.27)\end{array}$ & $\begin{array}{l}0.2^{*} \\
(0.08)\end{array}$ & $\begin{array}{r}0.64 * * \\
(0.27)\end{array}$ \\
\hline GFCF & $\begin{array}{l}0.18^{*} \\
(0.04)\end{array}$ & $\begin{array}{r}0.04 \\
(0.12)\end{array}$ & $\begin{array}{l}0.19^{*} \\
(0.05)\end{array}$ & $\begin{array}{r}0.04 \\
(0.118)\end{array}$ & $\begin{array}{l}0.16^{*} \\
(0.05)\end{array}$ & $\begin{array}{r}0.05 \\
(0.12)\end{array}$ & $\begin{array}{l}0.16^{*} \\
(0.05)\end{array}$ & $\begin{array}{r}0.04 \\
(0.12)\end{array}$ \\
\hline INF & $\begin{array}{c}-0.12^{* *} \\
(0.06)\end{array}$ & $\begin{array}{r}-0.15^{* * *} \\
(0.08) \\
\end{array}$ & $\begin{array}{l}-0.12 * * \\
(0.06)\end{array}$ & $\begin{array}{r}-0.15^{* * *} \\
(0.08) \\
\end{array}$ & $\begin{array}{l}-0.16^{*} \\
(0.06)\end{array}$ & $\begin{array}{r}-0.15^{* * *} \\
(0.08) \\
\end{array}$ & $\begin{array}{l}-0.16^{*} \\
(0.06)\end{array}$ & $\begin{array}{r}-0.16^{* * *} \\
(0.08) \\
\end{array}$ \\
\hline $\begin{array}{l}\text { No. of observations } \\
\text { Hausman test (p-vale) }\end{array}$ & 520 & & 520 & 520 & 520 & 520 & 520 & \\
\hline
\end{tabular}

Note: $*, * *$, and $* * *$ represents significance at $1 \%, 5 \%$ and $10 \%$ respectively. The coefficient of constant is ignored. Values in parenthesis represent robust standard errors. Hausman test p-value is shown in parenthesis.

\section{4- Conclusion}

To achieve a certain level of economic growth; the developing countries manipulate their currencies by applying devaluation policies. The findings of empirical literature regarding the relationship between devaluation and economic growth are not consistent. The financial systems in these countries are diversified. This study is an attempt to reconcile the conflicting literature by investigating the effect of undervaluation on economic growth in Belt \& Road countries in the presence of financial integration during 2001-2016 and 2013-2016. Since most of the BRI countries are developing and the financial integration is at a low level, there, we put a hypothesis that real exchange rate misalignment will play an important role in economic growth.

Considering the issue of endogeneity, the study relies on the GMM approach. The results of this study are according to the expectations, i.e., the real exchange misalignment is significant and positive. Financial integration also plays an essential and positive role in economic growth. The interaction terms of the real exchange rate and financial integration play a significant and negative role in economic growth. Moreover, several robustness checks like two-stage least squares, fixed and random effect models also confirm the results of the GMM approach.

The present study aims to investigate the role of financial openness in exchange-growth relationship in linear framework. Keeping in view the volatility of exchange rate, the study can be extended to investigate the nonlinearities associated in the exchange-growth relationship.

\section{References}

Abbas, S. M. A., \& Christensen, J. E. (2010). The role of domestic debt markets in economic growth: An empirical investigation for low-income countries and emerging markets. IMF Staff Papers. https://doi.org/10.1057/imfsp.2009.24

Baltagi, B. H. (2005). Econometric Analysis of Panel Data. In Econometric Theory. https://doi.org/10.1017/S0266466600006150

Béreau, S., Villavicencio, A. L., \& Mignon, V. (2012). Currency misalignments and growth: A new look using nonlinear panel data methods. Applied Economics. https://doi.org/10.1080/00036846.2011.577022

Bleaney, M., \& Greenaway, D. (2001). The impact of terms of trade and real exchange rate volatility on investment and growth in sub-Saharan Africa. Journal of Development Economics. https://doi.org/10.1016/S0304- 
3878(01)00147-X

Chinn, M. D., \& Ito, H. (2008). A New Measure of Financial Openness. Journal of Comparative Policy Analysis: Research and Practice. https://doi.org/10.1080/13876980802231123

Cottani, J. A., Cavallo, D. F., \& Khan, M. S. (2005). Real Exchange Rate Behavior and Economic Performance in LDCs. Economic Development and Cultural Change. https://doi.org/10.1086/451853

Dai, M., \& Xu, J. (2017). Firm-specific exchange rate shocks and employment adjustment: Evidence from China. Journal of International Economics. https://doi.org/10.1016/j.jinteco.2017.05.004

DAI, P. VAN, DELPACHITRA, S., \& COTTRELL, S. (2016). REAL EXCHANGE RATE AND ECONOMIC GROWTH IN EAST ASIAN COUNTRIES: THE ROLE OF FINANCIAL INTEGRATION. The Singapore Economic Review. https://doi.org/10.1142/s0217590816500168

Dogru, T., Isik, C., \& Sirakaya-Turk, E. (2019). The balance of trade and exchange rates: Theory and contemporary evidence from tourism. Tourism Management. https://doi.org/10.1016/j.tourman.2019.01.014

Dollar, D. (2005). Outward-Oriented Developing Economies Really Do Grow More Rapidly: Evidence from 95 LDCs, 1976-1985. Economic Development and Cultural Change. https://doi.org/10.1086/451959

Edwards, S. (1988). Real and monetary determinants of real exchange rate behavior: Theory and evidence from developing countries. Journal of Development Economics. https://doi.org/10.1016/0304-3878(88)90048-X

Elbadawi, I. A., Kaltani, L., \& Schmidt-hebbel, K. (2008). Foreign aid, the real exchange rate, and economic growth in the aftermath of civil wars. World Bank Economic Review. https://doi.org/10.1093/wber/lhm024

Gala, P. (2008). Real exchange rate levels and economic development: Theoretical analysis and econometric evidence. Cambridge Journal of Economics. https://doi.org/10.1093/cje/bem042

Hausman, J. A. (2006). Specification Tests in Econometrics. Econometrica. https://doi.org/10.2307/1913827

Hausmann, R., Pritchett, L., \& Rodrik, D. (2005). Growth accelerations. Journal of Economic Growth. https://doi.org/10.1007/s10887-005-4712-0

Ibarra, C. A. (2011). Capital flows and real exchange rate appreciation in Mexico. World Development. https://doi.org/10.1016/j.worlddev.2011.05.020

Lin, S., Shi, K., \& Ye, H. (2018). Exchange rate volatility and trade: The role of credit constraints. Review of Economic Dynamics. https://doi.org/10.1016/j.red.2018.05.002

Lucas, R. E. (1988). On the mechanics of economic development. Journal of Monetary Economics. https://doi.org/10.1016/0304-3932(88)90168-7

Mankiw, N. G., Romer, D., \& Weil, D. N. (1992). A Contribution to the Empirics of Economic Growth. The Quarterly Journal of Economics. https://doi.org/10.2307/2118477

Murray, M. P. (2007). Avoiding Invalid Instruments and Coping with Weak Instruments. Journal of Economic Perspectives. https://doi.org/10.1257/jep.20.4.111

MW, \& Enders, W. (2006). Applied Econometric Time Series. Journal of the American Statistical Association. https://doi.org/10.2307/2291367

Nouira, R., \& Sekkat, K. (2012). Desperately seeking the positive impact of undervaluation on growth. Journal of Macroeconomics. https://doi.org/10.1016/j.jmacro.2011.12.002

Pattillo, C., Poirson, H., \& Ricci, L. (2002). External debt and growth. Finance and Development.

Porcile, G., \& Lima, G. T. (2010). Real exchange rate and elasticity of labour supply in a balance-of-paymentsconstrained macrodynamics. Cambridge Journal of Economics. https://doi.org/10.1093/cje/bep065

Razin, O., \& Collins, S. M. (2010). Real-Exchange-Rate Misalignments and Growth. In The Economics of Globalization. https://doi.org/10.1017/cbo9780511619946.005

Razmi, A., Rapetti, M., \& Skott, P. (2012). The real exchange rate and economic development. Structural Change and Economic Dynamics. https://doi.org/10.1016/j.strueco.2012.01.002

Schröder, M. (2013). Should developing countries undervalue their currencies? Journal of Development Economics. https://doi.org/10.1016/j.jdeveco.2013.07.015

UNCTAD. (2018). World Investment Report 2018. Investmetn and New Industrial Policies. In United Nations Conference on Trade and Development. https://doi.org/10.1016/j.spinee.2004.12.003

Vieira, F. V., \& MacDonald, R. (2012). A panel data investigation of real exchange rate misalignment and growth. Estudos Econômicos (São Paulo). https://doi.org/10.1590/s0101-41612012000300001

Williamson, J. (1990). What Washington Means by Policy Reform. In Latin American Adjustment: How Much Has Happened?

World Bank. (2018). World Development Indicators Data Catalog. In The World Bank. 
Appendix

Table A1. List of BRI countries

\begin{tabular}{|c|c|c|c|c|c|}
\hline S. No & Country & S. No & Country & S. No & Country \\
\hline 1 & Albania & 25 & Jordan & 49 & Philippines \\
\hline 2 & Antigua and Barbuda & 26 & Kazakhstan & 50 & Qatar \\
\hline 3 & Armenia & 27 & Korea, Rep. & 51 & Romania \\
\hline 4 & Azerbaijan & 28 & Kuwait & 52 & Russian Federation \\
\hline 5 & Bahrain & 29 & Kyrgyz Republic & 53 & Saudi Arabia \\
\hline 6 & Bangladesh & 30 & Lao PDR & 54 & Senegal \\
\hline 7 & Belarus & 31 & Latvia & 55 & Singapore \\
\hline 8 & Bhutan & 32 & Lebanon & 56 & Slovak Republic \\
\hline 9 & Bolivia & 33 & Libya & 57 & Slovenia \\
\hline 10 & Bosnia and Herzegovina & 34 & Lithuania & 58 & South Africa \\
\hline 11 & Bulgaria & 35 & Macedonia, FYR & 59 & Sri Lanka \\
\hline 12 & Cambodia & 36 & Madagascar & 60 & Syrian Arab Republic \\
\hline 13 & China & 37 & Malaysia & 61 & Tajikistan \\
\hline 14 & Croatia & 38 & Maldives & 62 & Thailand \\
\hline 15 & Czech Republic & 39 & Moldova & 63 & Trinidad and Tobago \\
\hline 16 & Egypt, Arab Rep. & 40 & Mongolia & 64 & Tunisia \\
\hline 17 & Estonia & 41 & Morocco & 65 & Turkey \\
\hline 18 & Ethiopia & 42 & Myanmar & 66 & Turkmenistan \\
\hline 19 & Georgia & 43 & Nepal & 67 & Ukraine \\
\hline 20 & Hungary & 44 & New Zealand & 68 & United Arab Emirates \\
\hline 21 & India & 45 & Oman & 69 & Uzbekistan \\
\hline 22 & Iran, Islamic Rep. & 46 & Pakistan & 70 & Vietnam \\
\hline 23 & Iraq & 47 & Panama & 71 & Yemen, Rep. \\
\hline 24 & Israel & 48 & Papua New Guinea & & \\
\hline
\end{tabular}

